\title{
EDUCATIONAL SYSTEM IN THE WORK OF AMÉLIE NOTHOMB "GLOSSARY OF PROPER NAMES"
}

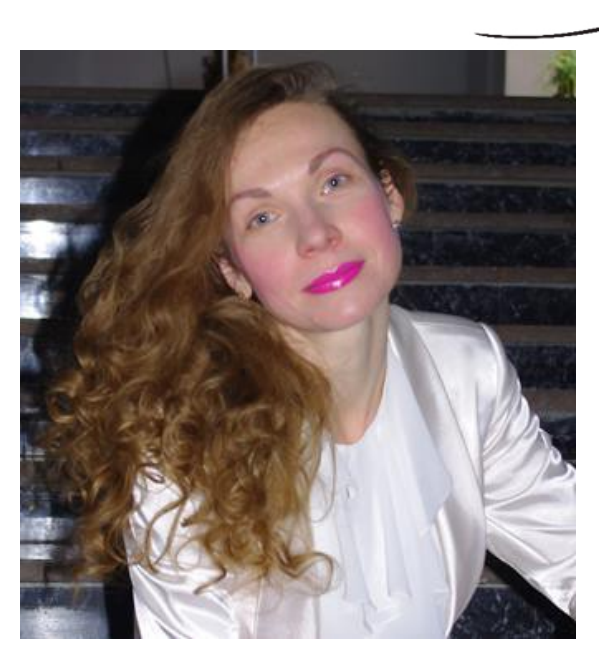

(C) Svitlana Kryvoruchko, Doctor of Philology, Associate Professor, Head of the Department of Romance Philology and Translation of the School of Foreign Languages, V. N. Karazin Kharkiv National University, Svobody sq., 4, Kharkiv, Ukraine, 61022, serka7@ukr.net

In the book "Dictionary of proper names" 2002 Belgian Francophone writer A. Nothomb interprets social system, embodies the idea of education's devastating impact on the psyche of a child and an adolescent. In theory of literature they singled out a genre - the novel of education, which upsets the psychological and social narratives around issues of identity formation. Conceptually the genre of "Dictionary of proper names" is formed on the basis of the story and novel features of novel education that on ideological level transformed into anti educational methods that were accepted and common.

By creating an artistic image of the chosen child A. Nothomb reveals educational system: pre-kindergarten, school, ballet education as criminal establishments employing inhumane professionals applying antipedagogical methods of education aimed at the destruction of freedom, joy, and even the health of future generations. The author destroys the "myth" of adequate educational system today, which was formed in the "family", "school", "children's art schools" refutes strict parenting practices of successful strong personality that cripples the psyche of the individual, makes him sick. At the level of subtext writer outlines humanistic perspective - the dominant trend in education should be a particular love for the individual, taking into consideration the psychological nuances of its' character.

Key words: A. Nothomb, genre, character, idea, education system.

Francophone Belgian writer that works on the boundary of XX-XXI centuries Amélie Nothomb (born 1966) draws attention to intellectual readership and literary critics. 
French, Hungarian, Russian and Ukrainian researchers analyse achievements of writer. There is a number of works dedicated to the writer : monograph L. Amanieux (Amanieux, 2009), theses G. Revial (Revial, 2012), O. A. Kulagina (Кулагина, 2012), article L. Marois (Marois, 2011), O. V. Makarevich (Макаревич, 2010), M. J. Byelyavskaja (Бєлявська, 2012) and others. Literary critics pay attention to the creative reflection phenomenon of identity in the works the writer, they analyze poetics and genre originality, they reveal ambivalence at the "author's mask", they comprehend mythological background, A. Nothomb attempt to overcome archetypes, distinguish the category "other" in terms of linguistic analysis. Understanding of social systems left unattended by researchers, that creatively uncovered in the heritage A. Notomb, in particular in the book "Dictionary of proper names" 2002 (Нотомб, 2008), in which the author represents the idea of the devastating impact of education on the psyche of the child and adolescent.

There is "romance-education" genre singled out in literary theory, which sets around the problem of psychological and social narratives identity formation. The origins of ideological orientation of "romance-education" are still in the parables of the Bible. Genre of the book "Dictionary of proper names" conceptually formed on the basis of stories and novels with features of "romance-education", that are transformed into anti educational methods on the ideological level, that were generally and widespread. Here we can see turnover of genre, which is appropriate track as "antieducational stories-novels".

A. Nothomb reveals the psychological nuances in the characters' actions, which are harmful to the harmonious development of the child, which form a psychological inferiority complex, and even cause physical harm to the human body and push to suicide. The writer depicts three educational systems: parental education at home, schooling, additional education (ballet school). The idea of education provided as dilemma and even as paradox: the desire of aspirations professionals to educate healthy successful person often ends with humiliating the child, with the result that all the actions of teachers become meaningless.

Plektruda's mother (not biological, but girl's aunt - Klyemans) transfers to a child own expectations and aspirations to realize her goal, which should be achieved by "daughter" - become a «star» (in works of A. Nothomb - outstanding ballerina). Girl damages her own health because of the desire to meet the expectations of her mother and requirements of teachers at ballet school. Plektruda do not eat anything, because the ideal dancer must be thin, she spends time at the ballet "stall", bringing her body can not withstand - Girl breaks a leg and must give up ballet, and her mother, who 
must support daughter in a difficult situation, vice versa is indifferent to the child. The idea of art as something beautiful is dethroned and represents a distortion of human life.

Teachers are represented as functionaries at elementary school, which do not include individual perception of the individual child, resulting stress is a general mood of ordinary school, which is considered the norm. The child accumulates stress, that encourages teenager to become suicidal. According to A. Nothomb salvation for the child that no one loved can only be the love. Plektruda is saved from suicide and indifference of adults by the lonely and psychologically traumatized youth Mathieu Saladin, his love makes the heroine a successful and self-fulfillment person - she becomes a singer.

The idea of pseudo education led connotations genre, in which has been transformed "romane-education", novel, "story". The writer reveals the existential loneliness of the heroine (young child, teenager) when puts accents on the search for the meaning of life, the phenomenon of death, which are embodied in the conflict of mother / daughter. Mother "killed" daughter its pseudo-care, it forms in the thinking of the child the asociality, absence-denial of children's «self», harmful for health food system - use only sweets.

The writer reveals the system of education, which is appropriate to apply for unique, talented child, but not for the usual child. For this A. Nothomb highlights "singularity" and exclusivity of heroine, who was born in a unique family, but the separation is most marked with the sign "minus". Mother of the girl kills her husband during pregnancy and falls behind bars: "Child hiccuping, and Lachetti seemed, if it escapes clockwork, counting seconds before the explosion... She moved sudden certainty... went to another room... found the revolver... back to bed. She looked at the beautiful face of a sleeping boy, took aim at him in the temple and whispered: - I love you, but has to protect his child. By bringing the gun firmly to Fabien's head she fired until the clip ended. She looked at the blood that spattered the wall. And calmly dialed the police: - I just killed my husband. Come " (Нотомб, 2008: 13). Subconsciously future mother felt that neither she nor her husband were able to adequately educate a child. She decided - "dead" father is better than the father, who does not earn money. So, obeying to unconscious animal instinct of self-preservation - protecting female offspring, the woman, by murdering her beloved husband, is trying to protect her child from its insolvent parent. 
The writer of the book reveals the psyche of a woman-mother, who is not satisfied with the usual routine: "I did well, when killed Fabien. He was not bad, but average " (Нотомб, 2008: 15). As an alternative to the usual routine the mother chooses a prison that makes her chosen - the killer of her husband. The mother wanted to give the child a special life, "give her infinity" (Нотомб, 2008: 16), for this she calls the girl a rare name of the Holy Martyr - Plektruda, but by this step she dooms the child to suffer, which is a program of Catholic collective unconscious. Mother tries to give her child what she was deprived of herself - the best (instead of an ordinary life - a unique life): "- She'll have a lot of problems because of this name. - But once people will understand that my daughter - unusual" (Нотомб, 2008: 17). Mother cuts off everything unnecessary from her child herself - she deprived her not only from her "normal" father, but also from the imperfect mother "the same night Lyusetta severed sheets, tied scraps and hanged" (Нотомб, 2008: 18).

To reveal failure of pedagogical principles, the writer creates the perfect metaphor for education - depicts the absurd situation of a child's fatality in the civilized cultural development, which is in conflict with the natural biological functions of people. Social imperfect parents should disappear as species - it's even better for the orphan to be educated by ideal "foreigners" than inferior "relatives" in order to crack the genetic code, to change evolutionary a vector of the family.

A. Nothomb, creating an artistic image of Plektruda, focuses on her unusualness and sends by allusions to Greek mythology - the goddess Aphrodite (Roman Venus). The virtue of the goddess was not only her flawless appearance - beauty, as much as charisma: Aphrodite aroused feelings of love, ability to like, no one was left indifferent about her. A. Nothomb makes this quality of Plektruda's character dominant: "The world has never seen a baby, who would arouse so much love to her" (Нотомб, 2008: 19). In Plektruda's psychological portrait writer introduces the idea of Nietzsche's "super-human": "... Plektruda's eyes had one indisputable virtue they shone with unearthly beauty. Infirm baby directed its target by abyss look of the magnetic strength ... those big beautiful eyes spoke... "Love Me!" "Your destiny - is to love me!" I was only eight weeks, but ... I am incredible, the highest being ' " (Нотомб, 2008: 19).

After suicide of heroine's mother, the baby is adopted by her aunt who as the girl's mother notices Plektruda's unusualness, her difference comparing to her own children, considering her as "... divine, bright, mysterious, rare creature" (Нотомб, 2008: 20) that "... like a fairy pixie" (Нотомб, 2008: 21). Creation of a unique heroine by the writer is required in order to solve the conflict of chosen / everyday, 
gifted / average, individual / system-society. A. Nothomb depicts the difficult path of talent establishment in mother / daughter conflicts, child / children's educational institutions, revealing the inadequacy of the existing education system. Plektruda comes to tradition, when, as well as other utters the first words "mama" (Нотомб, 2008: 22), "Рара" (Нотомб, 2008: 23), and at the age of three goes to a kindergarten.

Here appears the first misunderstanding of heroine's position as a chosen one. Plektruda's talent is rejected by the modern environment and it's highlight - unusual eyes girls - is an obstacle to dialogue with peers: "The whole thing is in her eyes ...Children cry when she looks at them at close range. And I must tell you, I understand them: when she looks at me, I became too embarrassed " (Нотомб, 2008: 26). So Plektruda is excluded from the kindergarten. It should draw attention to the social problem, which puts the writer at the wrong level of professionals who have to do their job - reaction of the teacher when he faces "unusual." The teacher instead of the child enters collective unconscious, tries to understand the character of the heroine and her entourage, contrary expels "foreign" from the child's establishment, what brings inconsistency, inadequacy of the system in relation to the individual: "... daughter was expelled from kindergarten because of her amazing eyes " (Нотомб, 2008: 26).

A. Nothomb continued implementation of conceptual archetype of Aphrodite in Plektruda's character when she gives the girl the ability to inspire others to creative self-realization: the girl's mother by communicating with her opened in her yet unknown possibilities: "Under careful look of the child, 28 years old woman raised the confidence of a young fairy and old witch that hided for some time " (Нотомб, 2008: 27). Realizing the difference of Plektruda, her aunt by her special treatment, instead of making her gently and carefully enter social system, reconciled with thinking of "majority", vice versa emphasized on her "otherness" - framed outside internal capacity, pushed to the rejection of individual by the crowd, formed conflict of an individual and system: "... passersby saw a young woman stepping on the street that led by the hand a tiny creature dressed as even princess of " Thousand and one nights " would dare. Near the school door this spectacle in turn caused surprise, laughter, emotion and - conviction " (Нотомб, 2008: 31).

By the plot of rejection of the girl by crowd A. Nothomb discloses the conflict of ideas, beauty / routine. The writer of this constant confirmation introduces in the literary work of art her own analysis of Moliere "Misanthrope", which gives an opportunity to compare Plektruda with Selymena. Like Selymena, Plektruda (with its "singularity" - "beauty") is not accepted by the community, and also as a grown 
woman a girl does not pay attention to it, does not notice the crowd, opposed to the majority that allows her to reach a higher level - become stronger.

At the age of 4 years girl realizes her goal - to make the world better by her own beauty. For this purpose she chooses art - ballet. A. Nothomb in the process of making strong personality represents the "institution" of ballet, ballet education to expose the shortcomings of the system, to demonstrate that the "beauty" is humiliation disease, it is "horrible." The writer shows how a talented child is disabled by adults "pseudo." Plektruda endowed with talent, that her teachers emphasize: "This child has eyes of a dancer - lady-teacher announced ... eyes ... in our case the most important thing and the most rare. If ballerina does not have a "look" of a dancer, her dance will never have inspiration " (Нотомб, 2008: 35). These teachers predict to the girl further professional perspective: "It is necessary to learn to dance, she has outstanding abilities" (Нотомб, 2008: 36).

At the ballet school A. Nothomb reveals the system of general education schools, which function is also to destroy the liberty of the individual human will power, psyche injury, the formation of an inferiority complex. The writer ironically reveals the conceptual basis of education, which is installed in school education: "There had to sit motionless for hours at a desk. And listen to the teacher, who spoke totally uninteresting things" (Нотомб, 2008: 37). A. Nothomb highlights dissonance of nature and civilization: a child who has a fast metabolism that causes its energy, has overcome these biological processes and abandons the natural mobility - "sit at the desk." Here is about the inability of the teacher to encourage students to focus on motivating children, distributed educational material manner to present - "listen uninteresting things."

The conflict teacher / student reveals the reluctance of teachers to understand the nuances of the child and adult antipathy that aims to suppress those children who distinguishes from the public. As it has been already noticed, the name of the girl is come off and her vocation "to be liked". According to the teacher, the girl "wants everybody to admire her but there’s nothing to admire!" (Нотомб, 2008: 40), because of it and it's begins to oppress her.

The humiliating atmosphere of the children's school canteen should be noted, which is shown by the writer, which visual purpose is to physically destroy future generations: "... the worst happened in the children's dining room, which ruled two ... characteristic smells - child vomiting and bleach ... waitress were passing the dishes of some unexplained food cloudy color ... in front of her there was a full bowl of 
greenish stuff, dotted with tiny pieces of brown meat ... warning that it will not go to the cafeteria until they eat all the way ... Once she overcame half, as it vomited right in the bowl, and here it became obvious why the dining room smells this way ... " (Нотомб, 2008: 40-41).

In the Plektruda's mind the school was a very unpleasant place, completely devoided of joy - "hell" (Нотомб, 2008: 43). The writer emphasizes that secondary school has absolutely no motivation for learning, children are not encouraged, without trying to generate interest in the subject. A. Notomb from girls' attitude brings moral educative process must be based on the interest of the child, the quest to acquire knowledge that is not trying to form a teachers' only key to knowledge - desire nothing more "( Нотомб, 2008: 47). So if modern educational systems are devoided of methodological leading principles - encouraging output is self-education, which is Plektruda's only way to get knowledge, "reading became a necessity, and she instantly captured this science ... Plektruda just needed to grow to true art ... During two days, she learned everything what a professional instructor could not teach her five months " (Нотомб, 2008: 47).

The writer makes parents enter the conflict with the teacher trying to explain intuitively the specifics of their home methods that proves the failure of school: "... we did nothing. Just show her a wonderful book that she wanted to read. This is what lacked in class " (Нотомб, 2008: 48). A sincere openness enhances parental conflict teacher / student as pseudo teacher "hate" (Нотомб, 2008: 48), and interpreted Plektruda's academic success as their own image.

A. Nothomb creates an artistic image of the teacher, who instead of teaching "good", tolerance, humanity of the children, sows discord between them, fueled scandal "Plektruda became the object of universal contempt" (Нотомб, 2008: 49). However, A. Nothomb depicts very differently the situation in ballet school. Plektruda's failure in secondary school is the contrast in attitudes towards girls in the art world: "... in a ballet school ... she was the Queen" (Нотомб, 2008: 49). A. Nothomb continues to develop the idea S. de Beauvoir ( "Magic Pictures"), which revealed the importance of the phenomenon of friendship in adolescence identity formation. To understand Plektruda's thinking A. Nothomb introduces her friends from ballet school - Rosalind to identify the psychological nuances of the child's mind. Rosalind treats Plektruda as ideal. Plektruda, in turn, felt emotional exaltation thanks to Rosalind: "This changed her life abruptly. How to explain the high value of friendship in front of the children? ... Friend in the eyes of a child - a man who himself chose him, a man who offers him her love freely, not by obligation. And because friendship for children - the highest 
luxury, and the luxury ... requires chosen soul. Friendship opens their festive face being " (Нотомб, 2008: 52). The writer emphasizes the importance of play for the child in the formation process, because it reveals in this way her personal potential.

On the one hand, girls' games were traditional - they played the wedding, on the other, their singularity manifested in the romantic vein - they drew a picture of death, because the art of ballet phenomenon becomes mandatory death finale. Death causes ballet aesthetic beauty. A. Nothomb depicts how games help children turn life into art.

The writer debunks "the myth": ballet - the art of beauty by revealing boring, traumatic, difficult existence of ballerina, who at one moment can become great. The ballet school is a prison - with iron discipline, with specific canons of beauty, girls with standard proportions - "fat cow" (Нотомб, 2008: 95), slim - "normal" (Нотомб, 2008: 95) goneri - "well done", "look at them was like skeletons, laughing" (Нотомб, 2008: 96). Teachers of the ballet school are devoided of any human feelings: "... in front of the adults was not a drop of kindness, they shone of cold scalpel that cuts last children swelling" (Нотомб, 2008: 97). The attitude to the future stars of ballet A. Nothomb compares with stringent methods of education of girls in medieval China. They were not allowed to eat - "food caused fear," "Every piece seemed superfluous" (Нотомб, 2008: 99), exhausted by constant exercise - "they passionately wanted only one thing - even for a minute to sit down," "Ballet machine resembled a convict galleys"( Нотомб, 2008: 98), the only salvation was a dream.

The reward for this suffering was a dance, which "must win" (Нотомб, 2008: 101). A. Nothomb explains the concept of teaching ballet education: "Our educational system is aimed so that you may obtain the essence of a dance: it is not the means, but the reward. And we have no right to allow the dance to those pupils who have not earned this award. Eight hours a day in the machine and empty mode may seem torment only for those who did not really want to dance. So if someone wants to leave, let him go! " (Нотомб, 2008: 101).

The worst thing turns out to rethink the rules of nature, resulting in broken physiological processes of humanistic ideals and human rights. Constant hunger and strenuous exercise lead to the disappearance of menstrual cycles of young girls that just turns teaching requirement: "... in the school, no one of the pupils had menstrual cycle, even in high school ... a lot of them didn't need pills: malnutrition is enough to forget about the menstruation and everything connected with it " (Нотомб, 2008: 103). 
The worst is that the result of inadequate educational pressure is absolute rejection of teenagers' own thoughts, desires, and personal subjection. Eventually Plektruda "endorsed most barbaric methods and became fond of Spartan spirit that prevailed at the school" (Нотомб, 2008: 104). Thus, A. Nothomb interprets art as a phenomenon, fueled by a victim of the people who should give up their lives for the high end. The writer stresses that tormented heroine had hard leg pain as a constant diet led to a lack of calcium in the bones and they did not survive. The heroine during rehearsals broke the femur and she became incompetent: "... you will never be able to dance" (Нотомб, 2008: 123).

The girl, who wanted to reach her goal they deprived the meaning of life on her way to it. A. Nothomb, by creating an artistic image of the selected child in the book "Dictionary of proper names," reveals the educational system: pre-kindergarten, school, ballet education as criminal establishments employing inhumane professionals applying antipedagogical methods of education aimed at the destruction of liberty joy and even the health of future generations. The writer by criticizing educational institutions trys to draw attention of imperfections of community to established practices that require rethinking, and even objections and prohibitions.

Thus, in the book "Dictionary of proper names" A. Nothomb destroys the "myth" of adequate educational system today, which was formed in the "family", "school", "children's art schools" refutes strict methods of upbringing strong successful individuals which mutilates the psyche of the individual, makes them sick. At the level of subtext, the writer outlines humanistic perspective - the dominant trend in education should be a particular love for the individual, taking into account the psychological nuances of his her character.

Further scientific research is appropriate to draw attention to the interpretation of the idea of love, which in veiled motives that the writer revealed in this work.

\section{REFERENCES}

Бадью, А. (2014). Столітmя [пер. $з$ франц. А. Рєпа]. Львів : Кальварія : НікаЦентр.

Баррі, П. (2008). Вступ до теорії: літературознавство та культурологія [пер. з англ. Погинайко О.]. К.: Смолоскип. 
Бєлявська, М. Ю.(2012). Інтерпретація класичних образів у сучасній літературі (на матеріалі творів Амелі Нотомб). Вісник львівського університету. Серія: Іноземні мови. - Львів.- вип. 20. - Ч . 1. - С. 41-46.

Кулагина, О. А. (2012). Языковое портретирование «чужого» как способ передачи этнокультурного диссонанса во франиузском языке. Автореферат диссертации. М. Режим доступу: http://www.dissercat.com/content/yazykovoeportretirovanie-chuzhogo-kak-sposob-peredachi-etnokulturnogo-dissonansa-vo$\underline{\text { frantsu }}$

Макаревич, О. В. (2010). Бинарные категории мылиления как основа философского мировосприятия в литературных сказках Амели Нотомб и Мишеля турнье. Вестник Нижегородского университета им. Н. И. Лобачевского, № 4-2. Режим доступу: http://cyberleninka.ru/article/n/binarnyekategorii-myshleniya-kak-osnova-filosofskogo-mirovospriyatiya-v-literaturnyhskazkah-ameli-notomb-i-mishelya-turnie

Нотомб, А. (2008). Словарь имён собственных [пер. с франц. И. Волевич]. М.: Иностранка.

Шалагінов, Б. Б. (2015). Опилки і лабіринт: Книга естетичних фрагментів. К. : Вид. Дім «Києво-Могилянська академія».

Amanieux, L. (2009). Le récit siamois. Identité et personnage dans l'oeuvre d'Amélie Nothomb. Paris : Editions Albin Michel.

Revial, G. (2012). Masque de l'écriture, écriture du masque Amélie Nothomb et le courant post-humain [position de thèse] Paris, Sorbonne. Режим доступу: http://www.paris-sorbonne.fr/IMG/pdf/Position_de_these_REVIAL.pdf

Marois, L. (2011). Le double mythique : la figure d'Eurydice dans «Mercure» d'Amélie Nothomb. Режим доступу:

http://pendientedemigracion.ucm.es/info/amaltea/revista/num3/marois.pdf

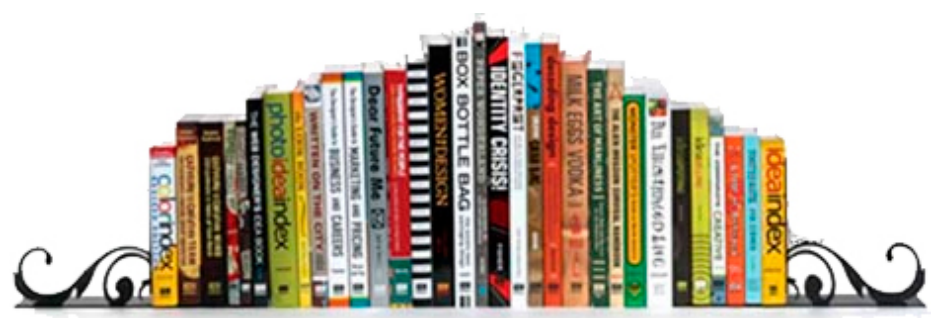

